Review paper

\title{
FACTORS AFFECTING IMMUNE RESPONSES IN HONEY BEES:
}

\section{AN INSIGHT}

\author{
Gurleen Kaur ${ }^{1}$ \\ Rohit Sharma 2* \\ Ashun Chaudhary ${ }^{3}$ \\ Randeep Singh ${ }^{1 *}$ \\ 1Plant Protection Division, PG Department of Agriculture, Khalsa College \\ Amritsar,143002, Punjab, India \\ 2Department of Rasashastra and Bhaishajya Kalpana, Faculty of Ayurveda, \\ Institute of Medical Sciences, Banaras Hindu University, Varanasi, 221005, Uttar \\ Pradesh, India \\ ${ }^{3}$ Department of Plant Sciences, School of Life Sciences, Central \\ University of Himachal Pradesh, Shahpur, Kangra, 176206, Himachal Pradesh, India \\ *Corresponding authors: singhrandeep83@hotmail.com, rohitsharma@bhu.ac.in \\ Received: 10 December 2020; accepted: 08 March 2021
}

\section{A bstract}

Honey bees pollinate various crops and wild plants which ensures food security. However, in this modern world, bees are suffering. Decreasing global domesticated and wild bee populations while the demand for agricultural pollination services is increasing is a matter of concern. Colony losses are driven by such factors or interactions as changing environmental conditions, exposure to agrochemicals, parasite and pathogens attack and decreased flower abundance and diversity. All these stresses individually or together affect the immune system of bees and consequently bee fitness. Poor nutrition is the key stressor as it directly suppresses the immune system and reduces host resistance to other stressors. To cope with these stresses, honey bees have well-developed individual and social immune systems which initiate several defence reactions, but its activation, maintenance and use are detrimental for bee survival as it occurs at the cost of bee health. This review summarizes the causal factors and their possible interaction responsible for immune suppression in honey bees.

Keywords: honey bee, immune suppression, interactions, nutrition, oxidative stress, stressors

\section{INTRODUCTION}

Honey bees are of great ecological, economic and scientific value. They provide various hive products of great significance with respect to nutrition, immunity and medication (Bhatnagar et al., 2020; Sharma et al., 2020) and are also essential for crop pollination (Jivan, 2013). Their contribution in the pollination of more than $80 \%$ crops and wild plants make them an important component of food security and biodiversity maintenance (Fontaine et al., 2005; Bascompte et al., 2006; Klein et al., 2007; Ollerton et al., 2011). Their value in pollination is fifty-four times the value of the honey they produce (Sanjerehei, 2014).
Despite their importance, the domesticated and wild bee populations have been reported to be declining globally at alarming rates in the United States, Europe, India, China, Israel and Turkey (Gross, 2007; Currie et al., 2010; van der Zee et al., 2012; Sihag, 2014). Currently available honey bee populations are not keeping pace with the growing demands for agricultural pollination services, which puts stress on the global pollination capacity (Aizen \& Harder, 2009). A number of factors have been documented for the honey bee colony losses including parasitic and pathogenic infections, pesticidal toxicities, nutrient deficiencies and changing environmental conditions (vanEngelsdorp \& Meixner, 2010; 
Goulson et al., 2015; Stanimirović et al., 2019). Recently, the honey bee colony losses have been linked to an impaired immune system (Alaux et al., 2014; Steinmann et al., 2015). The immune system consists of certain organs and mechanisms which protect the organism from such threats as parasites, pathogens and foreign particles by recognizing them and then responding against them (Larsen et al., 2019). Insects have well developed innate immune systems which protect them from different stresses (Strand, 2008). Currently, the most studied insect is the fruit fly, Drosophila melanogaster, and its immunological studies are used as a reference not only for insects but for humans as well (Larsen et al., 2019). Honey bees possess a similar immune system to that of fruit flies and mosquitoes except that the bees have nearly one third genes for immunity as compared to such solitary insects as flies, moths and mosquitoes (Evans et al., 2006). Instead, honey bees have more genes related to their behavior and social organization skills including for odour receptors and food collection (HCSC, 2006). So, predictably the lower number of immunity related genes in honey bees is a consequence of well-developed social immunity which lowers the pressure on individual immunity. Thus, such social insects as honey bees defend themselves through both social as well as individual immunities. Social immunity mainly relies on behavioral responses (Simone-Finstrom, 2017) whereas individual immunity consists of humoral and cellular defense responses (Schmid-Hempel, 2005).

Immunocompetence depends upon several internal as well as external factors including diet, age, caste, pesticides, parasites, pathogens and environment (Jones, 1962; Wilson-Rich et al., 2008; Mao et al., 2013; Negri et al., 2015). These factors individually or together led to immune suppression (Alaux et al., 2010a; Pettis et al., 2012; Boncristiani et al., 2012; Pettis et al., 2013). Evidences of a link between reduced bee immunity and stress factors have been provided by Yoshida (1988); Vandame \& Belzunces (1998); Szymaś \& Jędruszuk (2003); Shen et al. (2005); Higes et al. (2007); Gregorc et al. (2012);
Steinmann et al. (2015); Brandt et al. (2016). Recent studies associated with honey bee immunity have been receiving more attention as faded immunity increase the probability of disease occurrence and progress (Pamminger et al., 2018).

The present review describes the current knowledge on immunity types in honey bees, factors affecting these immunities and the result of possible interaction among such factors on overall bee health.

\section{TYPES OF IMMUNITY}

Being eusocial, honey bees are highly prone to infections and other diseases as they live in closed environment and share food with one another (Cremer et al., 2007). Honey bees lower the risk of disease outbreaks through a combination of their well-built behaviours at a social level (social immunity) and immune responses at individual levels (individual immunity) (DeGrandiHoffman \& Chen, 2015). The social and individual immunities together provide a defence against various stresses. The social and innate defence responses against the various foreign bodies are summarized in Tab. 1.

Social immunity due to behavioural cooperation among members of a colony defends against invading pathogens and combats disease transmission risks that arise from group living (Cremer et al., 2007). It is provided through the following behavioural defences: (1) nest building and guarding i.e. disinfection of nesting material with antimicrobial products (propolis) collected from outside and guarding of nest entrance by guard bees (Cremer et al., 2007), (2) grooming i.e. removal of foreign particle, pollen or pathogen from oneself (auto-grooming) or from another adult hive mate (allo-grooming) (Simone-Finstrom, 2017), (3) hygienic behaviour via removal of diseased or parasitized brood by adult bees (Wilson-rich et al., 2009; Larsen et al., 2019), (4) undertaking i.e. removal of dead adults (Evans \& Spivak, 2010), (5) altruistic behaviour i.e. voluntary leaving of colonies by sick adults and dying outside the colony (DeGrandi-Hoffman \& Chen, 2015; Larsen et al., 2019), (6) thermoregulatory behaviour i.e. raising tempera- 
ture (social fever) of hive against heat sensitive pathogens (DeGrandi-Hoffman \& Chen, 2015; Simone-Finstrom, 2017), (7) offspring cannibalism i.e. feeding of nurse bees on brood which died due to food scarcity or extreme temperatures (Cremer et al., 2007; Larsen et al., 2019) and (8) polyethism i.e. age-related task allocation reduces interaction between different age groups (Simone-finstrom, 2017).

Individual immunity consists of mechanisms which make an individual capable of resisting, tolerating and eliminating a foreign particle. It has basically two components, innate and adaptive, but the latter is found in higher vertebrates and lacking in insects (Larsen et al., 2019). Honey bees' innate immune system, the first line of defence, restricts invading pathogens or other foreign particles with physical or mechanical barriers- exoskeleton, trachea and peritrophic membrane lining the gut of insect (Gliński \& Jarosz, 1995; Evans \& Spivak, 2010). If foreign particles break the barriers and enter the insect's body, then there is second line of defence with constitutive and induced defence responses (SchmidHempel, 2005; Laughton et al., 2011). Constitutive defence consisting cellular and humoral responses is always present, non-specific and instant in effect (Gillespie et al., 1997; Schmid-Hempel, 2005). Induced responses occur only after the recognition of a specific pathogen, and thus require more production time with specific

Table 1.

Summarizes the social and innate defence responses against the various foreign bodies

\begin{tabular}{|c|c|}
\hline Immune Рагаmeter & Foreign Body \\
\hline \multicolumn{2}{|r|}{ Social Immunity } \\
\hline Social fever & Fungi (Starks et al., 2000) \\
\hline Plant Resins & $\begin{array}{l}\text { Bacteria (Antúnez et al., 2008) } \\
\text { Fungi (Simone-Finstrom \& Spivak, 2012) }\end{array}$ \\
\hline Grooming & $\begin{array}{l}\text { Tracheal mite (Danka \& Villa, 1998) } \\
\text { Varroa (Guzman-Novoa et al., 2012) }\end{array}$ \\
\hline Hygienic behaviour & $\begin{array}{l}\text { Fungi (Gilliam et al., 1983) } \\
\text { Bacteria (Spivak \& Reuter, 2001) } \\
\text { Varroa (Ibrahim et al., 2007) }\end{array}$ \\
\hline Division of labour & Pathogen transmission (Naug \& Camazine, 2002) \\
\hline \multicolumn{2}{|r|}{ Innate Immunity } \\
\hline Phagocytosis & Small bacteria and virus (James \& Xu, 2012; Larsen et al., 2019) \\
\hline Nodulation & Fungi (James \& Xu, 2012; Larsen et al., 2019) \\
\hline Encapsulation & Large parasites (James \& Xu, 2012; Larsen et al., 2019) \\
\hline Antibacterial activity & Neonicotinoids and bacteria (Dickel et al., 2018) \\
\hline Antimicrobial peptides & $\begin{array}{l}\text { Varroa and Virus (Gregorc et al., 2012) } \\
\text { Pesticides (Garrido et al., 2013) } \\
\text { Bacteria, fungi, protozoa (Danihlík et al., 2015) }\end{array}$ \\
\hline $\begin{array}{l}\text { RNA interference, } \\
\text { dsRNA }\end{array}$ & Virus (Brutscher et al., 2015) \\
\hline $\begin{array}{l}\text { Prophenoloxisade } \\
\text { activation }\end{array}$ & Microbial infection (Li et al., 2018) \\
\hline
\end{tabular}


and long-lasting effects. Induced responses produce antimicrobial peptides and proteins which are absent in healthy bees (Boman \& Hultmark, 1987). Haemocytes or blood cells are an essential component of cellular immunity and provide defence through phagocytosis, nodulation and encapsulation responses (Strand, 2008). Humoral defence includes the production of antibacterial immune proteins and enzymatic systems which regulate wound healing, melanin biosynthesis, phagocytosis, nodulation and encapsulation (Kaaya, 1993; Cerenius et al., 2008).

\section{FACTORS CAUSING IMMUNE SUPPRESSION}

Honey bee colony losses are linked to parasites, pathogens, pesticides, poor nutrition, climate change and changing management practices (van Engelsdorp \& Meixner, 2010; Generch et al., 2010; Potts et al., 2010; Goulson et al., 2015). The causal links between these factors and immune-suppression has been established (Shen et al., 2005; Steinmann et al., 2015). Several factors influencing bee immunity are illustrated in Fig. 1.

\section{Parasitic infestations}

Bees suffer from a wide range of parasitic mites. More than hundred mite species are associated with honey bees, but Varroa spp. and Tropilaelaps spp. (both ectoparasites) and Acarapis spp. (endoparasite) most threaten bee survival (Sammataro et al., 2000).

Ectoparasitic mite, Varroa destructor, a major threat to honey bees throughout the world, infests and kills a European honey bee colony within one to three years if no control measures are taken (Strauss et al., 2015). Additionally, Varroa further act as a vector to various bacteria (Gliński \& Jarosz, 1992), viruses (Allen \& Ball, 1996) and fungi (Liu, 1996). Immature and adult stages of this mite feed on the haemolymph of developing and adult honey bees through a single

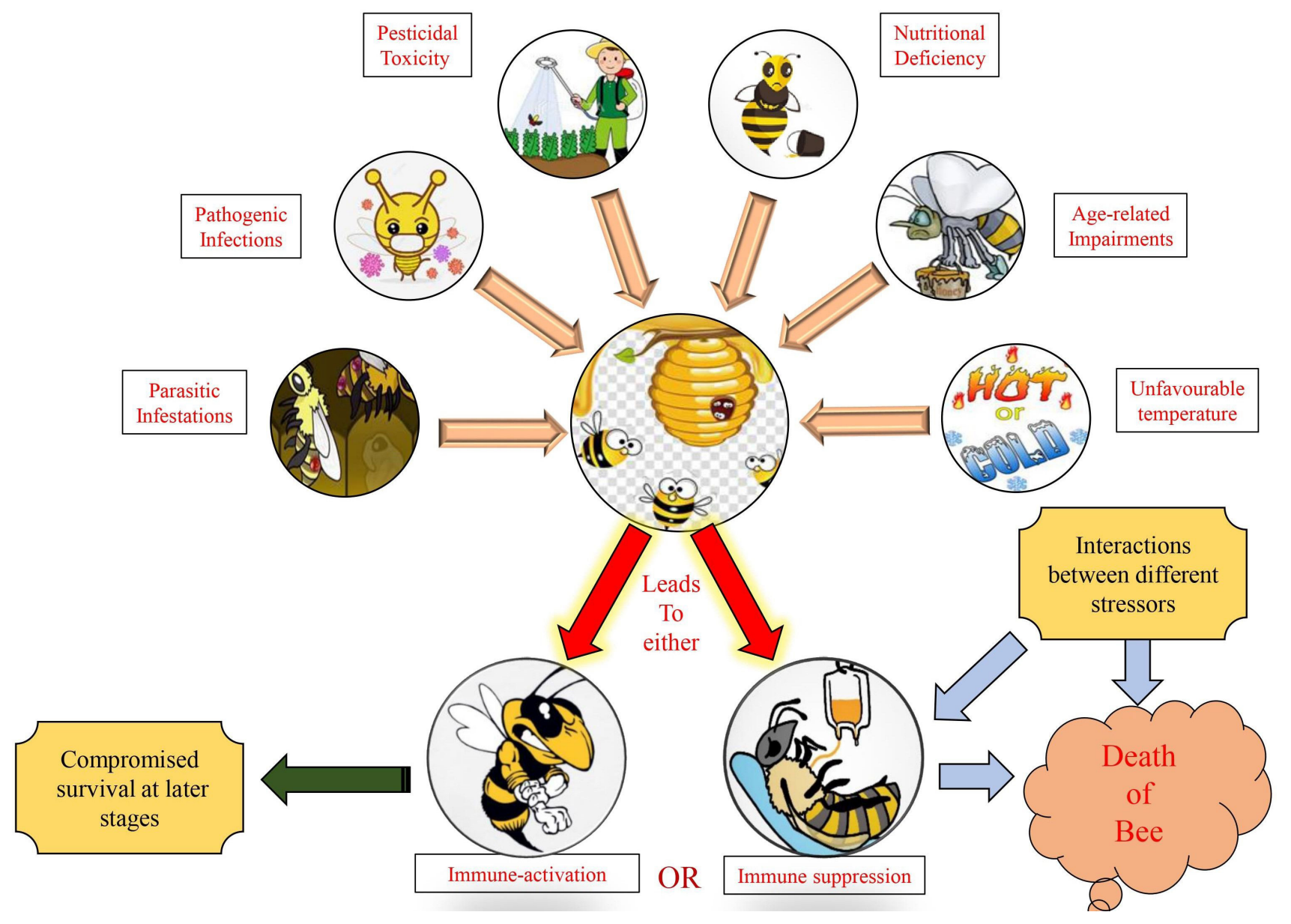

Fig. 1. Various factors influencing bee immunity. 
puncture hole. During feeding, mite's salivary secretions damage haemocytes and suppresses the wound healing responses, keeping wound open for days to ensure continuous feeding of its immature stages (Richards et al., 2011). Recent research has shown that Varroa feed primarily on fat bodies rather than haemolymph and these damaged fat tissues may cause immune suppression by altering the production of vitellogenins and antimicrobial peptides (Ramsey et al., 2019). Varroa infestation interferes with both cellular and humoral immunity and suppresses the cellular immune system by reducing total haemocyte count (THC), differential haemocyte count (DHC), surface area of haemocytes and clotting (Salem et al., 2006; Richards et al., 2011). Whereas, the altered expression of immune-responsive antibacterial peptides suppresses humoral immunity in Varroa-infested bees (Gregorc et al., 2012). Tropilaelapsspp. in Asia, another major ectoparasitic mite infesting European honey bees, has similar lifecycle as Varroa. They disturb the regulations of phagocytosis receptor gene and antimicrobial peptide encoding genes in infested honey bees (Khongphinitbunjong et al., 2015). On the other hand, endoparasitic mite, Acarapis woodi, enters the trachea of young bees and punctures the tracheal wall to suck haemolymph causing nutrient loss and damaged wing muscles. They also affect air flow and allow secondary infections through punctured wounds (Eischen, 1987). Feeding on haemolymph may reduce the number of haemocytes as reported in Varroa infested bees (Salem et al., 2006). Colonies infested with this mite have reduced social immunity as the bees become unable to thermoregulate due to damaged wing muscles (McMullan \& Brown, 2009).

\section{Pathogenic infections}

Like other organisms, honey bees are naturally infected with disease-causing pathogens including bacteria, viruses, fungi and protozoans, which along with other pests are considered as a reason behind the global honey bee decline (Ratnieks \& Carreck, 2010). Haemocytic sensitivity of honey bee immature and mature stages to American foul brood (AFB) infection was reported by Zakaria (2007). The bacterial pathogen Paenibacillus larvae, causative agent of AFB disease, suppress larval honey bees' innate immunity as the antibacterial peptide encoding gene's transcript levels are negatively correlated with the disease levels (Evans \& Pettis, 2005). They directly suppress the cellular immunity by damaging haemocytes in larvae (Gregorc \& Bowen, 1998).

Expression of genes encoding immunity-related enzymes and antibacterial peptides vary after infection with Nosema apis and Nosema ceranae (Antúnez et al., 2009). N. ceranae suppress both cellular and humoral immunities by degrading or hypertrophying host cells (Higes et al., 2007) and by reducing the expression of immunity related genes (Chaimanee et al., 2012). Nosema also causes energy stress in the host probably by competing for nutrients (Mayack \& Naug, 2009). Nosema lacks mitochondria and develop only after direct contact with the cytoplasm of its host cell which fulfils the requirement of an external energy source for reproduction of this microsporidia (Fries et al., 1996; Weidner et al., 1999; Martín-Hernández et al., 2011). Such heavily infested epithelial cells lining the bee gut assure poor nutrient absorption resulting in bees dying early death due to starvation (Liu, 1984). The Nosema-caused energetic stress reduces the trehalose levels in haemolymph (Mayack \& Naug, 2010) and affects the flight efficiency and thermoregulatory ability of bees (Campbell et al., 2010). Nosema directly interfere with the innate immune responses by reducing apoptosis in host bees through enhanced transcription of apoptosis protein-(iap)-2 inhibitor gene (Kurze et al., 2015).

Pathogenic viruses also cause immune suppression. Mites act as a vector or activator to turn the asymptotic presence of viruses into lethal infections (Shen et al., 2005). The occurrence of such pathogenic viruses as deformed-wing virus (DWV) (Shen et al., 2005; Ryabov et al., 2014), Kashmir-bee virus (KBV) (Shen et al., 2005) and acute bee paralysis virus (ABPV) (Ball \& Allen, 1988) are correlated with the presence of mites, and together they suppress the immunity of host 
bees. DWV vectored by Varroa suppresses host immunity by interfering with the nuclear factorkappa B (NF- $\left.{ }_{k} \mathrm{~B}\right)$ protein family and reducing the Toll pathway controlled antiviral response (Nazzi et al., 2012). Presence of Tropilaelaps, another mite, is also linked to infections of DWV (Forsgren et al., 2009). Such immune responses as melanisation and encapsulation correlate negatively with DWV levels in a host (Di Prisco et al., 2016). Threats posed by DWV-Varroa association become more severe in the presence of additional stresses including poor diet and pesticides which further promote virus replication (Nazzi \& Pennacchio, 2014; Goulson et al., 2015). The interference of neonicotinoids with the NF- ${ }_{K} B$ immune signalling reduces immune responses and promotes the DWV replication in honey bees bearing covert infections (Di Prisco et al., 2013). DWV replication in several honey bee body tissues including fat bodies (Fievet et al., 2006) regulate various physiological processes including immune defences through vitellogenin (Trenczek \& Faye, 1988). The interference of DWV replication with the expression of vitellogenin may be responsible for its lower levels in collapsed colonies in comparison to healthy colonies (Dainat et al., 2012b).

\section{Temperature variations}

For the well-being of the entire colony including immature and mature stages, the hive temperature is maintained between $32-35^{\circ} \mathrm{C}$ by the resident bees (Kronenberg \& Heller, 1982; Seeley, 2014). They use fanning and evaporative cooling mechanisms to combat higher temperature whereas cluster formation or metabolic heat generation through contraction and relaxation of flight muscles combat lower temperature (Southwick \& Heldmaier, 1987). Elevated temperatures induce in honey bees a heat shock response with an increased expression of heat shock proteins. At the same time, heat shock suppresses the multiple immunity-related genes (McKinstry et al., 2017). Compared to summer bees, winter bees exhibit a more reduced expression of immunity related genes and higher DWV loads (Steinmann et al., 2015), and the occurrence of Varroa and DWV reduces their life span (Dainat et al., 2012a). Temperature also affects the flight muscles of bees, which either by shivering or through heat loss maintain a temperature range for efficient working of muscles. Any temperature below this range is responsible for the failure of wing, leg and body muscles (Esch, 1988) which may affect social immunity.

Relatively high and low temperatures cause oxidative stress in arthropods (LopezMartinez et al., 2008), which occurs when there is imbalance of free radical production and antioxidant activity (Sies, 2000). Its interference with such cell components as DNA (increased mutations due to breakdown of single-strand, base deletion or degradation) (Jena, 2012), protein (reduced enzymatic activity due to modification of amino acids and rupturing of peptides) (Davies, 2016) and lipids (destruction of cell membrane by lipid peroxidation) (Cheeseman, 1993) affect the physiology of an organism (Simone-Finstrom et al., 2016). Exposure to pesticides, heat, cold, ultraviolet radiations and hydrogen peroxide induces oxidative stress in honey bees (Li et al., 2016) and bees respond to these stresses through varying expression levels of detoxifying or immunity related genes (Zhu et al., 2016). Modified environmental conditions in greenhouses induce oxidative stress and thus adversely affect the cellular and humoral immune systems of honey bees (Morimoto et al., 2011). Simulated heat waves alter the vitellogenin level which protects against oxidative stress (Bordier et al., 2017). Glutathione S-transferases (GSTs) play an important role in oxidative stress management and insecticide resistance, but variations in temperature change GST-related gene expression in a time dependent manner (Yan et al., 2013). Due to oxidative damage, bees face severe survival (Perry et al., 2015; Chakrabarti et al., 2020) and memory issues (Farooqui, 2008).

Hive transportation provides pollination services to different crops, and transported bees underwent transport stress due variable temperatures, humidity, pressures and vibrations 
(Melicher et al., 2019). Migratory bees have more oxidative damage than stationary bees (SimoneFinstorm et al., 2016). Transport stress affects both, individual immunity by downregulating the genes associated with immunity as well as social immunity by decreased thermoregulation (Melicher et al., 2019). Migratory bees have a short life span compared to stationary bees (Simone-Finstorm et al., 2016). Transportation also reduces the hypopharyngeal gland size in nurse bees which is essential for brood food production (Ahn et al., 2012).

Apart from direct effects, varying temperature in different seasons create conditions suitable for infestation by various parasites and pathogens (Le Conte \& Navajas, 2008). The death of honey bee colonies in winters is closely associated with mite attack (van Dooremalen et al., 2012). DWV titres increase between summer and fall when mite incidences increase as well (Gauthier et al., 2007; Dainat et al., 2012b). The expression of immunity related gene (eater) decreases from summer to fall and then increases from fall to winter (Dainat et al., 2012b). High relative humidity combined with low temperatures enhances the chalkbrood development (Flores et al., 1996). Suboptimal brood temperatures increase the susceptibility of adults to pesticides (Medrzycki et al., 2010).

\section{Pesticidal toxicity}

Pesticides especially insecticides as well as fungicides and herbicides are reported to harm honey bees (Belzunces et al., 2012) either individually or synergistically with other stresses (Vadame \& Belzunces, 1998). Honey bees may be directly exposed to pesticides when visiting crop flowers during pesticide application or indirectly when coming in contact with a crop after pesticide application (May et al., 2015). They also become exposed when pesticides are directly applied to hives for the control of various bee enemies or diseases (Martel et al., 2007). Short-term effects of pesticides include instant bee death and long-term effects include morphological deformities, compromised foraging, impaired learning, weakened thermoregulation, exploitation of nutritional reserves and reduced immunities (Alaux et al., 2010a; Henry et al., 2012; Sánchez-Bayo et al., 2016; Meikle et al., 2016). Neonicotinoid (imidacloprid, thiacloprid, clothianidin etc.) and pyrethroid (ethofenprox and bifenthrin) insecticides interfere with haemocyte densities and affect cellular immunity (Brandt et al., 2016; Perveen \& Ahmad, 2017). They reduce antimicrobial activity of haemolymph and responses including wound healing, melanisation and encapsulation (Brandt et al., 2016; Brandt et al., 2017) and induce such cell deformities as de-nucleation, nuclei side displacement, ruptured cell wall, distorted cell shape and agglutination (Perveen \& Ahmad, 2017). Fungicides increase the transcript levels of enzyme related to melanisation, while insecticides and herbicides decrease them (Gregorc et al., 2012). Thymol and coumaphos acaricides downregulate genes involved in detoxification pathways and those genes whose products are involved in humoral (Basket) and cellular (Dscam) defence responses (Boncristiani et al., 2012), whereas flumethrin upregulate the expression of genes that encode antimicrobial peptides and immunity-related proteins (Garrido et al., 2013). Also, direct interferences of azole fungicides and glyphosate herbicide with Cytochrome P450 enzyme system, known to play a role in pesticide resistance and detoxification (Claudianos et al., 2006), affects the innate immunity of honey bees (Yoshida, 1988; Gregorc et al., 2012). Glyphosate also alters midgut microbial communities which defend honey bees against various pathogens (Dai et al., 2018; Motta et al., 2018). Apart from directly affecting cellular immunity (Cousin et al., 2013), herbicides cause indirectly food shortages and nutritional stress by removing alternative food source for bees (Albrecht, 2005; May et al., 2015).

Further, honey bees respond to pesticide induced oxidative stress (Chakrabarti et al., 2015) by increasing the activity of such antioxidant enzymes glutathione peroxidase and catalase (Balieira et al., 2018). In addition to pesticides, antibiotics cause immune suppression by downregulating the expression of immune-related genes (Li et al., 2019). 


\section{Nutritional deficiency}

Proper nutrition is imperative for the maintenance of an individual's health and disease prevention (Sharma \& Prajapati, 2014). Pollen and honey/nectar serve as key components in the honey bee's diet. Pollen, being a source of protein, provides many essential amino acids to bees for peptide synthesis in immune pathways (DeGrandi-Hoffman \& Chen, 2015). On the other hand, honey is a source of carbohydrates and provides energy for various metabolic processes associated with cellular and humoral immune responses (DeGrandi-Hoffman \& Chen, 2015). Thus, proper nutrition plays a role in the maintenance of the immune system. Short-term nutritional deprivation downregulates the immune system, whereas food access rapidly upregulates the immune system of insects (Siva-Jothy \& Thompson, 2002). Both individual and social immunities are modified by protein consumption. Glucose oxidase (GOX) activity, a parameter of social immunity, greatly increases with pollen consumption in bees (Alaux et al., 2010b). GOX act as a catalyst in the oxidation process of $\beta$-D-glucose into gluconic acid and hydrogen peroxide. The antiseptic nature of hydrogen peroxide helps in colony food sterilization (White Jr et al., 1963).

Protein deficiency reduces metabolic cell activity but increases total haemocyte count and granulocyte count (Szymaś \& Jędruszuk, 2003). This may occur as a compensatory mechanism for protein deficiency or reduced metabolic cell activities. Diet diversity also affects immune competence levels because polyfloral diets have more GOX activity compared to monofloral diets (Alaux et al., 2010b).

The effectiveness of individual and social immunity is directly related to the nutritional status of a colony. Invasion by such outer parasites as Varroa disturbs this relationship and hence supresses the immune system (DeGrandi-Hoffman \& Chen, 2015). Nosema feeding patterns on honey bees elevates their hunger level, reduces nutrient absorption and causes energetic stress leading to downregulation of the immune system (Martín-Hernández et al., 2011). This type of energetic stress is further enhanced by pesticides, and adverse effects could be seen in haemolymph sugar levels, foraging and thermoregulatory behaviours (Alaux et al., 2010a; Mayack \& Naug, 2010). Starved bees might modulate the vitellogenin levels which induce early foraging in infected bees and these bees died during foraging due to the energetic stress (Amdam \& Omholt, 2003; Nelson et al., 2007; Mayack \& Naug, 2009). Compared to pollen restriction (nutritional stress), pollen ingestion upregulates the immunity-related genes (Corona et al., 2019). Furthermore, the treatment of nutrient-deficient honey bee colonies with antibiotics had more pronounced adverse effects - reduced lifespan, hypopharyngeal gland development, nutrient and immune gene expression and enhanced viral loads (Li et al., 2019).

Honey bees develop certain mechanisms to react to pollen shortage in their colony. They cannibalize their young brood to maintain the older brood but during a long-term pollen shortage they even stop rearing which affects colony strength and social immunity (Brodschneider \& Crailsheim, 2010). Stress related to transportation and habitat change may also occurs due to reduced diversity or nutrition. Polyfloral diets, good source of nutrition, enhance immunityrelated enzymes and increase the resistance to such stresses (Huang, 2012). The use of pollen substitutes during dearth periods also reduces the total haemocyte count and metabolic activities of cells but the reductions are still lower than in protein free diets (Szymaś \& Jędruszuk, 2003).

\section{Age-related impairments}

Age-associated immune dysfunction, also known as "immune senescence", results in increased susceptibility to infections and impaired functioning of other systems (Ponnappan \& Ponnappan, 2011; Sharma et al., 2019). Similarly, the expression of immunity-related genes also varies with the age of bees. Brood has a higher haemocyte density than adults with maximum THC in pupal stage. Nurse bees have a higher fat-body mass and foragers a higher phenoloxidase activity, which generally increases with 
ontogeny (Wilson-Rich et al., 2008). In simple words, the development of an adult from nurse to forager is accompanied by both reduced haemocytes and fat body content and increased phenoloxidase and GOX activity (Schmid et al., 2008; Alaux et al., 2010a). Furthermore, the presence of a dominant haemocyte type varies with the age, from granulocyte dominance in European honey bee larvae to plasmatocyte dominance in adults (Richardson et al., 2018). Expression levels of a cytochrome P450 gene not only vary from highest in the egg stage to lowest in the adult stage but also within a single stage with maximum expression in the first instar larva and brown-eyed pupa (Zhu et al., 2016). Hence, minimum haemocyte densities and reduced cytochrome P450 expression in older bees indicates lower immunity in foragers as compared to younger stages. However, this age-dependent immune suppression is considered beneficial for bees as the foragers already have higher death rates due to foraging exhaustion. Because maintaining the immune system is a costly process, reduced immunities among foragers helps in the redistribution or saving of energy at colony levels (Schmid et al., 2008).

\section{Synergistic interactions}

Besides individually, these factors interact to supress the immune system more negatively. Moreover, immune suppression by one factor creates conditions favourable for other factors and thus reduces the survival of infected bees. Interrelationships among colony's nutritional state, immunity, Varroa and viruses have been well elaborated by DeGrandi-Hoffman \& Chen (2015). Colonies without Varroa parasitism have optimum brood rearing and colony growth which facilitate sufficient resource collection and proper nutrition, leading to a built--up immunity which reduces viral loads and ensures proper colony growth. However, the presence of Varroa can reverse this (DeGrandi-Hoffman \& Chen, 2015). A Varroa-virus association becomes more dangerous in the presence of such additional stresses as pesticides and poor nutrition (Nazzi \& Pennacchio, 2014; Goulson et al., 2015). Pesticides especially neonicotinoids promote virus replication by interfering with the expression of the NF- ${ }_{k} \mathrm{~B}$ gene family (Di Prisco et al., 2013). Workers infested with Varroa have compromised protein levels which cannot be raised even if sufficient pollen is provided (van Dooremalen et al., 2013). Nosema feeding patterns also induce nutritional or energetic stress in bees and interfere with both individual and social immunities (Mayack \& Naug 2009; Campbell et al., 2010; Chaimanee et al., 2012). Neonicotinoids and fipronil promote Nosema infections in colony by suppressing immunity-related genes (Aufauvre et al., 2014) or by affecting GOX activity (Alaux et al., 2010a). Inhibition of cytochrome P450 mediated ergosterol synthesis by azole fungicides increases insecticidal toxicity (Johnson et al., 2013).

Similar to insecticides, fungicidal residues also promote Nosema infections in colonies but their mechanisms are not known (Pettis et al., 2013). Unfavourable temperatures reduce the expression of immunity-related genes (Steinmann et al., 2015; McKinstry et al., 2017) and enhance Varroa, viral, fungal infections and susceptibility to pesticides (Flores et al., 1996; Medrzycki et al., 2010; Steinmann et al., 2015). High and low temperatures, pesticides and UV radiations cause oxidative stress in honey bees (Li et al., 2016) and this stress through cellular damages suppresses innate immunity. Natural compounds in the food of honey bees upregulate the immune system by detoxifying certain pesticides, but pollen and honey deficiency downregulates it (Mao et al., 2013; Negri et al., 2015; Corona et al., 2019).

Food collection by honey bees strongly depends on outside weather. Adverse climate conditionsrainfall, high winds and extreme temperature range restrict bee foraging (Riessberger \& Crailsheim, 1997) and cause nutritional stress in the colonies. Improper nutrition thus plays a central role in immune suppression by reducing resistance to Varroa, Nosema, viruses and pesticides (Huang, 2012). Interrelationships between the various stress factors are shown in Fig. 2. 


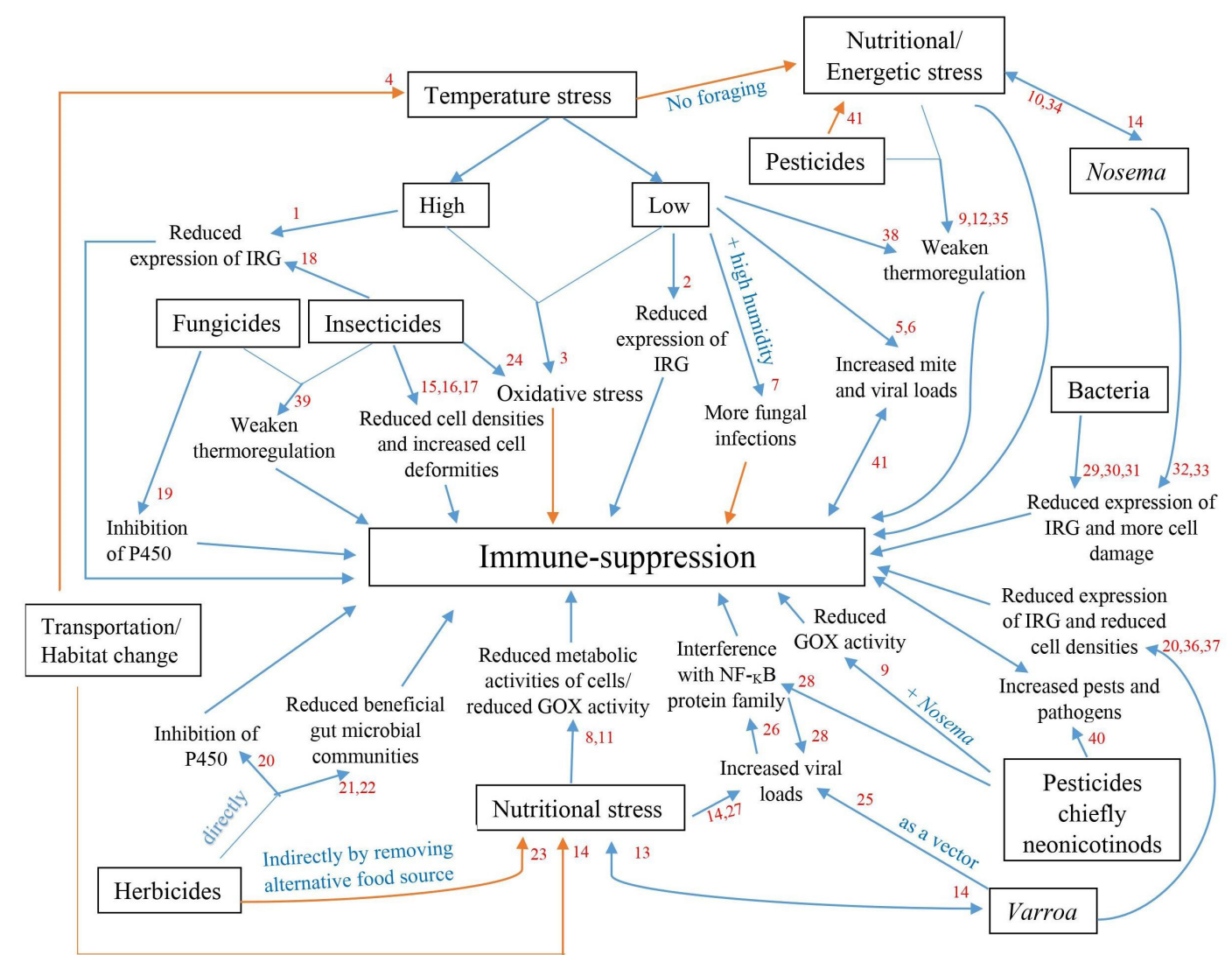

Fig. 2. Interrelationships between different stress factors downregulating immune system of honey bees. IRG, immunity related genes; GOX, glucose oxidase. Blue arrows show effects supported by literature. Red arrows show possible effects with less literature support. Numeric values indicate the references of supporting literature. 1 Mckinstry et al. (2017); 2 Steinmann et al. (2015); 3 Lopez-Martinez et al. (2008); 4 Melicher et al. (2019); 5 Dainat et al. (2012b); 6 Gauthier et al. (2007); 7 Flores et al. (1996); 8 Szymaś \& Jędruszuk (2003); 9 Alaux et al. (2010a); 10 Martin-Hernandez et al. (2011); 11 Alaux et al. (2010b); 12 Mayack \& Naug (2010); 13 DeGrandhi-Hoffmman \& Chen (2015); 14 Huang (2012); 15 Brandt et al. (2016); 16 Perveen \& Ahmad (2017); 17 Brandt et al. (2017); 18 Boncristiani et al. (2012); 19 Yoshida (1988); 20 Gregorc et al. (2012); 21 Motta et al. (2018); 22 Dai et al. (2018); 23 May et al. (2015); 24 Chakrabarti et al. (2015); 25 Shen et al. (2005); 26 Nazzi et al. (2012); 27 Goulson et al. (2015); 28 DiPrisco et al. (2013); 29 Evans \& Pettis (2005); 30 Gregorc \& Bowen (1998); 31 Zakaria (2007); 32 Higes et al. (2007); 33 Chaimanee et al. (2012); 34 Mayack \& Naug (2009); 35 Campbell et al. (2010); 36 Salem et al. (2006); 37 Richards et al. (2011); 38 Esch (1988); 39 Vandame \& Belzunces (1998); 40 Sánchez-Bayo et al. (2016); 41 Meikle et al. (2016).

\section{USING IMMUNE SYSTEM ITSELF REDUCES HOST FITNESS}

The maintenance of homeostasis is crucial to all forms of life, but environmental fluctuations and other stressors constantly threaten it (Baena-González, 2010; Clissold et al., 2013; Ahima, 2016). In order to neutralize the threat and to ensure survival under such situations, the stress response mobilizes the energy sources of an organism's body. Energy sources are shifted from growth or reproduction related biosynthetic processes to metabolic activities that enhances stress tolerance resulting in accelerated senescence (Baena-González, 2010; Sharma \& Martins, 2020). In this context, stress response is not helpful but relatively harmful, predisposing individuals to other problems (Rabasa \& Dickson, 2016).

Honey bees respond to any stress initially by recognition followed by the activation of signalling pathways and elimination of pathogen through humoral and cellular mechanisms (Larsen et al., 2019). Activation and use of immune systems against different stressors are costly; during 


\section{J. APCL. SUl. VOL. 65 IVD. 12021}

parasitism, such costs are usually masked by the host through compensatory resource intake (Moret \& Schmid-Hempel, 2000). The restoration of immune systems through feeding demonstrates a strong association between energy costs and maintenance of an effective immune system (Siva-Jothy \& Thompson, 2002). Varroa parasitism increases energy costs and reduces the survival of host honey bees (Aldea \& Bozinovic, 2020). Another cost of immune activation could be the elimination of beneficial microflora from the gut of honey bees (Gilliam, 1997). Riessberger-Gallé et al. (2015) provided experimental evidence that the cost of using the immune system reduces survival in immunechallenged bees as compared to control bees. In response to endogenous bacteria, honey bees activate their immune system by upregulating immunity-related genes, but at the same time, the gene- encoding storage protein (Hexamerin 70b) is downregulated (Janashia \& Alaux, 2016). This could be the reason behind increased food intake during parasitism. In addition to survival, the cost of activated immune system also affects the learning behaviour of bees (Mallon et al., 2003). Immuno-challenged workers and drones initially respond by increasing antimicrobial peptides (AMPs) but later AMP decreases because of its maintenance cost (Laughton et al., 2011). Those honey bees, which showed enhanced AMP production in response to bacteria, had a lower colony-production rate, possibly due to the higher production cost of AMPs (Evans \& Pettis, 2005). Thus, it is predictable that the use of the immune system compromises bee health.

\section{PERSPECTIVES AND FUTURE DIRECTIONS}

Honey bees have well developed mechanisms at individual and social levels to naturally cope up with different stresses, and proper nutrition is of the utmost importance for their regulation. Major factors responsible for immunosuppression in honey bees are poor nutrition, unfavourable temperatures, pesticide toxicity, parasites and pathogens. Moreover, honey bee age also affects the immune system. Downregulation of the immune system with increasing age is considered somewhat beneficial for bees as immune-system maintenance is costly and older bees already have higher mortalities due to foraging exhaustion (Schmid et al., 2008). All the stressors are directly or indirectly related to one another and together they harm bees as shown earlier in Fig 2. Occurrence of any one of the stressors makes conditions ideal for the co-occurrence of other stressors as well. The occurrence of nutritional stress in a colony apart from directly suppressing immunity also reduces resistance to other such stresses as Nosema, Varroa, viruses and pesticides (Huang, 2012). So, nutrition can concluded to be the root of honey bees' defence system as it influences the expression of certain immunity-related genes and production of antimicrobial peptides (Alaux et al., 2011) and increases pesticide tolerance in bees (Mao et al., 2013; Negri et al., 2015). Furthermore, the high cost of defence responses to different stressors are detrimental for honey bee colony health as they affect their survival and productivity (Evans \& Pettis, 2005; Riessberger-Gallé et al., 2015).

In addition to these major factors, we want to highlight the adverse effects of oxidative stress originated as a repercussion of different threatening situations. Since oxidative stress affects the overall well-being of a honey bee colony, future research should focus on the mechanisms by which oxidative stress affect the immunity or health of bees. One factor causing oxidative stress in bees is migratory beekeeping which has both many benefits and disadvantages as it affects the immunity and ultimately the survival of bees. Future research is needed to thoroughly understand the factors and mechanisms governing transportation stress and strategies to reduce it. It is now well understood that chances of occurrence and progress of a disease increases with diminished immunity so steps should be taken to combat this issue.

\section{CONCLUSION}

The present report provides comprehensive information on the types of immunity in honey 
bees, factors affecting these immunities and their possible interaction responsible for immune suppression in honey bees. Honey-bee health suffers not only because of various stressors but also because of the activation and response of the high-cost immune system, so the focus should be on practices that actually save bees from facing stresses. Most of the stresses are anthropogenic in origin and could be managed through the adjustment of timings for pesticide applications, microclimate manipulation in case of domesticated bees, maintaining a strategic balance between migratory and stationary colony environment and the use of alternative flora for bees during dearth periods. In addition, sufficient and timely availability of high quality food, both pollen and honey, enables bees to avoid most stresses i.e. parasite or pathogen, pesticide, temperature and transport. Furthermore, those stresses which cannot be avoided, they are tolerated by mechanisms including compensatory resource intake if sufficient food is available.

\section{REFERENCES}

Ahima, R. S. (2016). Principles of energy homeostasis, In: Ahima, R. S. (Eds.), Metabolic Syndrome: A Comprehensive Textbook (pp. 311326). Springer International Publishing, Cham.

Ahn, K., Xie, X., Riddle, J., Pettis, J., Huang, Z. Y. (2012). Effects of long distance transportation on honey bee physiology. Psyche, 2012. https://doi. org/10.1155/2012/193029

Aizen, M. A., \& Harder, L. D. (2009). The global stock of domesticated honey bees is growing slower than agricultural demand for pollination. Current Biology, 19(11), 915-918. https://doi.org/10.1016/j. cub.2009.03.071

Alaux, C., Brunet, J. L., Dussaubat, C., Mondet, F." Tchamitchan, S., Cousin, M., ... Le Conte, Y. (2010a). Interactions between Nosema microspores and a neonicotinoid weaken honeybees (Apis mellifera). Environmental Microbiology, 12(3), 774-782. $\quad$ https://doi.org/10.1111/j.1462-

\subsubsection{3.x}

Alaux, C., Crauser, D., Pioz, M., Saulnier, C., Le Conte, Y. (2014). Parasitic and immune modulation of flight activity in honey bees tracked with optical counters. Journal of Experimental Biology, 21719), 3416-3424. https://doi.org/10.1242/jeb.105783

Alaux, C., Dantec, C., Parrinello, H., Le Conte, Y. (2011). Nutrigenomics in honey bees: digital gene expression analysis of pollen's nutritive effects on healthy and varroa-parasitized bees. BMC Genomics, 12, 496. https://doi.org/10.1186/1471-2164-12-496

Alaux, C., Ducloz, F., Crauser, D., Le Conte, Y. (2010b). Diet effects on honeybee immunocompetence. Biology Letters, 6(4), 562-565. https://doi. org/10.1098/rsbl.2009.0986

Albrecht, H. (2005). Development of arable weed seedbanks during the 6 years after the change from conventional to organic farming. Weed Research, 45(5), 339-350. https://doi.org/10.1111/ j.1365-3180.2005.00472.x

Aldea, P." \& Bozinovic, F. (2020). The energetic and survival costs of Varroa parasitism in honeybees. Apidologie, 51, 997-1005. https://doi. org/10.1007/s13592-020-00777-y

Allen, M., \& Ball, B. (1996). The incidence and world distribution of honey bee viruses. Bee World, 773), 141-162. https://doi.org/10.1080/000 5772X.1996.11099306

Amdam, G. V., \& Omholt, S. W. (2003). The hive bee to forager transition in honeybee colonies: the double repressor hypothesis. Journal of Theoretical Biology, 223(4), 451-464. https://doi.org/10.1016/ S0022-5193(03)00121-8

Antúnez, K., Harriet, J., Gende, L., Maggi, M., Eguaras, M., Zunino, P. (2008). Efficacy of natural propolis extract in the control of American Foulbrood. Veterinary Microbiology, 137(3-4), 324-331. https://doi. org/10.1016/j.vetmic.2008.04.011

Antúnez, K., Martín-Hernández, R., Prieto, L., Meana, 


\section{J. APRC. SCLI. VOL. 65 NO. 1 2021}

A., Zunino, P., Higes, M. (2009). Immune suppression in the honey bee (Apis mellifera) following infection by Nosema ceranae (Microsporidia). Environmental Microbiology, 77(9), 2284-2290. https://doi. org/10.1111/j.1462-2920.2009.01953.x

Aufauvre, J., Misme-Aucouturier, B., Viguès, B., Texier, C., Delbac, F., Blot, N. (2014). Transcriptome analyses of the honeybee response to Nosema ceranae and insecticides. PLoS One, 9(3), e91686. https://doi. org/10.1371/journal.pone.0091686

Baena-González, E. (2010). Energy signalling in the regulation of gene expression during stress. Molecular Plant, 3(2), 300-313. https://doi. org/10.1093/mp/ssp113

Balieira, K. V. B., Mazzo, M., Bizerra, P. F. V., Guimarães, A. R. D. J. S., Nicodemo, D., Mingatto, F. E. (2018). Imidacloprid-induced oxidative stress in honey bees and the antioxidant action of caffeine. Apidologie, 49(5), 562-572. https://doi.org/10.1007/s13592018-0583-1

Ball, B. V., \& Allen, M. F. (1988). The prevalence of pathogens in honey bee (Apis mellifera) colonies infested with the parasitic mite Varroa jacobsoni. Annals of Applied Biology, 173(2), 237244. https://doi.org/10.1111/j.1744-7348.1988. tb03300.x

Bascompte, J., Jordano, P., Olesen, J. M. (2006). Asymmetric coevolutionary networks facilitate biodiversity maintenance. Science, 312(5772), 431433. https://doi.org/10.1126/science.1123412

Belzunces, L. P., Tchamitchian, S., Brunet, J. L. (2012). Neural effects of insecticides in the honey bee. Apidologie, 43(3), 348-370. https://doi. org/10.1007/s13592-012-0134-0

Bhatnagar, P." Lata, P., Singh, F." Singh, S. (2020). Hive Products and Their Uses. Biotica Research Today, ¿(8), 808-811.

Boman, H. G., \& Hultmark, D. (1987). Cellfree immunity in insects. Annual Reviews of Microbiology, 41, 103-126. https://doi.org/10.1146/ annurev.mi.41.100187.000535

Boncristiani, H., Underwood, R., Schwarz, R., Evans, J. D., Pettis, J. (2012). Direct effect of acaricides on pathogen loads and gene expression levels in honey bees Apis mellifera. Journal of Insect Physiology, 58(5), 613-620. https://doi.org/10.1016/j. jinsphys.2011.12.011

Bordier, C., Dechatre, H., Suchail, S., Peruzzi, M., Soubeyrand, S., Pioz, M., ... Alaux, C. (2017). Colony adaptive response to simulated heat waves and consequences at the individual level in honeybees (Apis mellifera). Scientific Reports, 72760). https:// doi.org/10.1038/s41598-017-03944-x

Brandt, A., Gorenflo, A., Siede, R., Meixner, M., Büchler, R. (2016). The neonicotinoids thiacloprid, imidacloprid, and clothianidin affect the immunocompetence of honey bees (Apis mellifera L.). Journal of Insect Physiology, 86, 40-47. https://doi.org/10.1016/j. jinsphys.2016.01.001

Brandt, A., Grikscheit, K., Siede, R., Grosse, R., Meixner, M. D., Büchler, R. (2017). Immunosuppression in Honeybee Queens by the Neonicotinoids Thiacloprid and Clothianidin. Scientific Reports, 74673). https://doi.org/10.1038/s41598-017-04734-1

Brodschneider, R., \& Crailsheim, K. (2010). Nutrition and health in honey bees. Apidologie, 47(3), 278294. https://doi.org/10.1051/apido/2010012

Brutscher, L. M., Daughenbaugh, K. F., Flenniken, M. L. (2015). Antiviral defense mechanisms in honey bees. Current Opinion in Insect Science, 10, 71-82. https://doi.org/10.1016/j.cois.2015.04.016

Campbell, J., Kessler, B., Mayack, C., Naug, D. (2010). Behavioural fever in infected honeybees: parasitic manipulation or coincidental benefit? Parasitology, 13710), 1487-1491. https:// doi.org/10.1017/S0031182010000235

Cerenius, L., Lee, B. L., Söderhäll, K. (2008). The proPOsystem: pros and cons for its role in invertebrate immunity. Trends in Immunology, 296), 263-271. https://doi.org/10.1016/j.it.2008.02.009 
Chaimanee, V., Chantawannakul, P., Chen, Y., Evans, J. D., Pettis, J. S. (2012). Differential expression of immune genes of adult honey bee (Apis mellifera) after inoculated by Nosema ceranae. Journal of Insect Physiology, 58(8), 1090-1095. https://doi. org/10.1016/j.jinsphys.2012.04.016

Chakrabarti, P." Carlson, E. A., Lucas, H. M., Melathopoulos, A. P." Sagili, R. R. (2020). Field rates of Sivantom (flupyradifurone) and Transform (sulfoxaflor) increase oxidative stress and induce apoptosis in honey bees (Apis mellifera L.). PLoS One, 15(5), e0233033. https://doi.org/10.1371/ journal.pone.0233033

Chakrabarti, P., Rana, S., Sarkar, S., Smith, B., Basu, P. (2015). Pesticide-induced oxidative stress in laboratory and field populations of native honey bees along intensive agricultural landscapes in two Eastern Indian states. Apidologie, 46(1), 107-129. https://doi.org/10.1007/s13592-014-0308-2

Cheeseman, K. H. (1993). Mechanisms and effects of lipid peroxidation. Molecular Aspects of Medicine, 14(3), 191-197. https://doi. org/10.1016/0098-2997(93)90005-X

Claudianos, C., Ranson, H., Johnson, R. M., Biswas, S., Schuler, M. A., Berenbaum, M. R., Feyereisen, R., Oakeshott, J. G. (2006). A deficit of detoxification enzymes: pesticide sensitivity and environmental response in the honeybee. Insect Molecular Biology, 15(5), 615-636. https://doi.org/10.1111/ j.1365-2583.2006.00672.x

Clissold, F. J., Coggan, N., Simpson, S. J. (2013). Insect herbivores can choose microclimates to achieve nutritional homeostasis. Journal of Experimental Biology, 216(11), 2089-2096. https://doi. org/10.1242/jeb.078782

Corona, M., Branchiccela, B., Madella, S., Chen, Y., Evans, J. (2019). Decoupling the effects of nutrition, age and behavioral caste on honey bee physiology and immunity. BioRxiv, 667931. https://doi. org/10.1101/667931

Cousin, M., Silva-Zacarin, E., Kretzschmar, A., El Davies, M. J. (2016). Protein oxidation and
Maataoui, M., Brunet, J. L., Belzunces, L. P. (2013). Size changes in honey bee larvae oenocytes induced by exposure to paraquat at very low concentrations. PLoS One, 8(5), e65693. https:// doi.org/10.1371/journal.pone.0065693

Cremer, S., Armitage, S. A., Schmid-Hempel, P. (2007). Socialimmunity. CurrentBiology, 1716),R693-R702. https://doi.org/10.1016/j.cub.2007.06.008

Currie, R. W., Pernal, S. F., Guzmán-Novoa, E. (2010). Honey bee colony losses in Canada. Journal of Apicultural Research, 49(1), 104-106. https://doi. org/10.3896/IBRA.1.49.1.18

Dai, P., Yan, Z., Ma, S., Yang, Y., Wang, Q., Hou, C., ... Diao, Q. (2018). The herbicide glyphosate negatively affects midgut bacterial communities and survival of honey bee during larvae reared in vitro. Journal of Agricultural and Food Chemistry, 66(29), 77867793. https://doi.org/10.1021/acs.jafc.8b02212

Dainat, B., Evans, J. D., Chen, Y. P." Gauthier, L." Neumann, P. (2012a). Dead or alive: deformed wing virus and Varroa destructor reduce the life span of winter honeybees. Applied and Environmental Microbiology, 78(4), 981-987. https://doi. org/10.1128/AEM.06537-11

Dainat, B., Evans, J. D., Chen, Y. P., Gauthier, L., Neumann, P. (2012b). Predictive markers of honey bee colony collapse. PLoS One, $\lambda 2$ ), e32151. https://doi.org/10.1371/journal.pone.0032151

Danihlík, J., Aronstein, K., Petřivalský, M. (2015). Antimicrobial peptides: a key component of honey bee innate immunity: Physiology, biochemistry, and chemical ecology. Journal of Apicultural Research, 54(2), 123-136. https://doi.org/10.1080/ 00218839.2015 .1109919

Danka, R. G., \& Villa, J. D. (1998). Evidence of autogrooming as a mechanism of honey bee resistance to tracheal mite infestation. Journal of Apicultural Research, 371), 39-46. https://doi.org/1 0.1080/00218839.1998.11100953 


\section{J. APRC. SUL. UOL. 65 NOL. 12021}

peroxidation. Biochemical Journal, 473(7), 805825. https://doi.org/10.1042/BJ20151227

DeGrandi-Hoffman, G., \& Chen, Y. (2015). Nutrition, immunity and viral infections in honey bees. Current Opinion in Insect Science, 10, 170-176. https://doi. org/10.1016/j.cois.2015.05.007

Di Prisco, G., Annoscia, D., Margiotta, M., Ferrara, R., Varricchio, P., Zanni, V., ... Pennacchio, F. (2016). A mutualistic symbiosis between a parasitic mite and a pathogenic virus undermines honey bee immunity and health. Proceedings of the National Academy of Sciences, 173(12), 3203-3208. https://doi. org/10.1073/pnas.1523515113

Di Prisco, G., Cavaliere, V., Annoscia, D., Varricchio, P., Caprio, E., Nazzi, F., Gargiulo, G., Pennacchio, F. (2013). Neonicotinoid clothianidin adversely affects insect immunity and promotes replication of a viral pathogen in honey bees. Proceedings of the National Academy of Sciences, 110(46), 1846618471. https://doi.org/10.1073/pnas.1314923110

Dickel, F., Münch, D., Amdam, G. V., Mappes, J., Freitak, D. (2018). Increased survival of honeybees in the laboratory after simultaneous exposure to low doses of pesticides and bacteria. PLoS One, 13(1), e0191256. pone.0191256

Eischen, F. A. (1987). Overwintering performance of honey bee colonies heavily infested with Acarapis woodi(Rennie). Apidologie, 18(4), 293-304. https:// doi.org/10.1051/apido:19870401

Esch, H. (1988). The effects of temperature on flight muscle potentials in honeybees and cuculiinid winter moths. Journal of Experimental Biology, 135, 109-117.

Evans, J. D., \& Pettis, J. S. (2005). Colony-level impacts of immune responsiveness in honey bees, Apis mellifera. Evolution, 59(10), 2270-2274. https://doi. org/10.1111/j.0014-3820.2005.tb00935.x

Evans, J. D., \& Spivak, M. (2010). Socialized medicine: individual and communal disease barriers in honey bees. Journal of Invertebrate Pathology, 103, S62-S72. https://doi.org/10.1016/j.jp.2009.06.019

Evans, J. D., Aronstein, K., Chen, Y. P., Hetru, C., Imler, J. L., Jiang, H.,... Hultmark, D. (2006). Immune pathways and defence mechanisms in honey bees Apis mellifera. Insect Molecular Biology, 75(5), 645-656. https://doi.org/10.1111/j.1365-2583.2006.00682.x

Farooqui, T. (2008). Iron-induced oxidative stress modulates olfactory learning and memory in honeybees. Behavioral Neuroscience, 122(2), 433447. https://doi.org/10.1037/0735-7044.122.2.433

Fievet, J., Tentcheva, D., Gauthier, L., De Miranda, J., Cousserans, F., Colin, M. E., Bergoin, M. (2006). Localization of deformed wing virus infection in queen and drone Apis mellifera L. Virology journal, 3(16). https://doi.org/10.1186/1743$422 \times-3-16$

Flores, J. M., Ruiz, J. A., Ruz, J. M., Puerta, F., Bustos, M., Padilla, F., Campano, F. (1996). Effect of temperature and humidity of sealed brood on chalkbrood development under controlled conditions. Apidologie, 274), 185-192. https://doi.org/10.1051/ apido:19960401

Fontaine, C., Dajoz, I., Meriguet, J., Loreau, M. (2005). Functional diversity of plant-pollinator interaction webs enhances the persistence of plant communities. PLoS Biology, 4(1), el. https://doi. org/10.1371/journal.pbio.0040001

Forsgren, E., De Miranda, J. R., Isaksson, M., Wei, S., Fries, I. (2009). Deformed wing virus associated with Tropilaelaps mercedesae infesting European honey bees (Apis mellifera). Experimental and Applied Acarology, 472), 87-97. https://doi.org/10.1007/ s10493-008-9204-4

Fries, I., Feng, F., da Silva, A., Slemenda, S. B., Pieniazek, N. J. (1996). Nosema ceranae n. sp. (Microspora, Nosematidae), morphological and molecular characterization of a microsporidian parasite of the Asian honey bee Apis cerana(Hymenoptera, Apidae). European Journal of Protistology, 32(3), 356-365. https://doi.org/10.1016/S0932-4739(96)80059-9 
Garrido, P. M., Antúnez, K., Martín, M., Porrini, M. P., Zunino, P." Eguaras, M. J. (2013). Immune-related gene expression in nurse honey bees (Apis mellifera) exposed to synthetic acaricides. Journal of Insect Physiology, 59(1), 113-119. https://doi.org/10.1016/j. jinsphys.2012.10.019

Gauthier, L., Tentcheva, D., Tournaire, M., Dainat, B., Cousserans, F., Colin, M. E., Bergoin, M. (2007). Viral load estimation in asymptomatic honey bee colonies using the quantitative RT-PCR technique. Apidologie, 38(5), 426-435. https://doi.org/10.1051/ apido:2007026

Genersch, E., Von Der Ohe, W., Kaatz, H., Schroeder, A., Otten, C., Büchler, R., ... Meixner, M. (2010). The German bee monitoring project: a long term study to understand periodically high winter losses of honey bee colonies. Apidologie, 47(3), 332-352. https:// doi.org/10.1051/apido/2010014

Gillespie, J. P." Kanost, M. R., Trenczek, T. (1997). Biological mediators of insect immunity. Annual Review of Entomology, 42, 611-643. https://doi. org/10.1146/annurev.ento.42.1.611

Gilliam, M. (1997). Identification and roles of nonpathogenic microflora associated with honey bees. FEMS Microbiology Letters, 155(1), 1-10. https://doi.org/10.1111/j.1574-6968.1997.tb12678.x

Gilliam, M., Taber III, S., Richardson, G. V. (1983). Hygienic behavior of honey bees in relation to chalkbrood disease. Apidologie, 14(1), 29-39.

Gliński, Z, \& Jarosz, J. (1992). Varroa jacobsoni as a carrier of bacterial infections to a recipient bee host. Apidologie, 23(1), 25-31. https://doi. org/10.1051/apido:19920103

Gliński, Z., \& Jarosz, J. (1995). Mechanical and biochemical defences of honey bees. Bee World, 76(3), 110-118. https://doi.org/10.1080/000 5772X.1995.11099257

Goulson, D., Nicholls, E., Botias, C., Rotheray, E. L. (2015). Bee declines driven by combined stress from parasites, pesticides and lack of flowers. Science, 3476229). https://doi. org/10.1126/science.1255957

Gregorc, A., \& Bowen, I. D. (1998). Histopathological and histochemical changes in honeybee larvae (Apis mellifera L.) after infection with Bacillus larvae, the causative agent of American foulbrood disease. CellBiology International, 22(2), 137-144. https://doi.org/10.1006/cbir.1998.0232

Gregorc, A., Evans, J. D., Scharf, M., Ellis, J. D. (2012). Gene expression in honey bee (Apis mellifera) larvae exposed to pesticides and Varroa mites (Varroa destructor). JournalofinsectPhysiology, 58(8), 10421049. https://doi.org/10.1016/j.jinsphys.2012.03.015

Gross, M. (2007). Bee puzzles. Current Biology, 1711), R389. https://doi.org/10.1016/j.cub.2007.05.027

Guzman-Novoa, E., Emsen, B., Unger, P., EspinosaMontaño, L. G., Petukhova, T. (2012). Genotypic variability and relationships between mite infestation levels, mite damage, grooming intensity, and removal of Varroa destructor mites in selected strains of worker honey bees (Apis mellifera L.). Journal of Invertebrate Pathology, 170(3), 314-320. https://doi. org/10.1016/j.jip.2012.03.020

Henry, M., Beguin, M., Requier, F., Rollin, O., Odoux, J. F., Aupinel, P., ... Decourtye, A. (2012). A common pesticide decreases foraging success and survival in honey bees. Science, 336(6079), 348-350. https:// doi.org/10.1126/science.1215039

HCSC (The Honeybee Genome Sequencing Consortium) (2006). Insights into social insects from the genome of the honeybee Apis mellifera. Nature, 443(7114), 931-949. https://doi.org/10.1038/ nature05260

Higes, M., García-Palencia, P." Martín-Hernández, R., Meana, A. (2007). Experimental infection of Apis mellifera honeybees with Nosema ceranae (Microsporidia). Journal of Invertebrate Pathology, 94(3), 211-217. https://doi.org/10.1016/j. jip.2006.11.001 


\section{Ј. APPC. SCL. VOL. 65 IIV. 12021}

Huang, Z. (2012). Pollen nutrition affects honey bee stress resistance. Terrestrial Arthropod Reviews, 5(2), 175-189. https://doi. org/10.1163/187498312X639568

Ibrahim, A., Reuter, G. S., Spivak, M. (2007). Field trial of honeybee colonies bred formechanisms of resistance against Varroa destructor. Apidologie, 38(1), 67-76. https://doi.org/10.1051/apido:2006065

James, R. R., \& Xu, J. (2012). Mechanisms by which pesticides affect insect immunity. Journal of Invertebrate Pathology, 109(2), 175-182. https://doi. org/10.1016/j.jp.2011.12.005

Janashia, I., \& Alaux, C. (2016). Specific immune stimulation by endogenous bacteria in honey bees (Hymenoptera: Apidae). Journal of Economic Entomology, 109(3), 1474-1477. https://doi. org/10.1093/jee/tow065

Jena, N. R. (2012). DNA damage by reactive species: Mechanisms, mutation and repair. Journal of Biosciences, 373),503-517.https://doi.org/10.1007/ s12038-012-9218-2

Jivan, A. (2013). The impact of pesticides on honey bees and hence on humans. Scientific Papers Animal Science and Biotechnologies, 46(2), 272-277.

Johnson, R. M., Dahlgren, L., Siegfried, B. D., Ellis, M. D. (2013). Acaricide, fungicide and drug interactions in honey bees (Apis mellifera). PLoS One, 8(1), e54092. https://doi.org/10.1371/journal. pone.0054092

Jones, J. C. (1962). Current concepts concerning insect hemocytes. American Zoologist, 2(2), 209246.

Kaaya, G. P. (1993). Inducible humoral antibacterial immunity in insects. In: Pathak, J. P. N. (Eds.), Insect Immunity (pp. 69-89). Springer, Dordrecht.

Khongphinitbunjong, K., de Guzman, L. I., Tarver, M. R., Rinderer, T. E., Chantawannakul, P. (2015). Interactions of Tropilaelaps mercedesae, honey bee viruses and immune response in Apis mellifera. Journal of
Apicultural Research, 54(1), 40-47. https://doi.org/1 $0.1080 / 00218839.2015 .1041311$

Klein, A. M., Vaissiere, B. E., Cane, J. H., SteffanDewenter, I., Cunningham, S. A., Kremen, C., Tscharntke, T. (2007). Importance of pollinators in changing landscapes for world crops. Proceedings of the Royal Society B: Biological Sciences, 274(1608), 303-313. https://doi.org/10.1098/rspb.2006.3721

Kronenberg, F., \& Heller, H. C. (1982). Colonial thermoregulation in honey bees (Apis mellifera). Journal of Comparative Physiology A, 148(1), 65-76. https://doi.org/10.1007/ BF00688889

Kurze, C., Le Conte, Y., Dussaubat, C., Erler, S., Kryger, P., Lewkowski, O., ... Moritz, R. F. (2015). Nosema tolerant honeybees (Apis mellifera) escape parasitic manipulation of apoptosis. PLoS One, 1910), e0140174. https://doi.org/10.1371/journal. pone.0140174

Larsen, A., Reynaldi, F. J., Guzmán-Novoa, E. (2019). Fundaments of the honey bee (Apis mellifera) immune system. Review. Revista Mexicana de Ciencias Pecuarias, 10(3), 705-728.

Laughton, A. M., Boots, M., Siva-Jothy, M. T. (2011). The ontogeny of immunity in the honey bee, Apis mellifera L. following an immune challenge. Journal of Insect Physiology, 577), 1023-1032. https://doi. org/10.1016/j.jinsphys.2011.04.020

Le Conte, Y., \& Navajas, M. (2008). Climate change: impact on honey bee populations and diseases. Revue Scientifique et Technique-Office International des Epizooties, 272), 499-510.

Li, G., Zhao, H., Liu, Z., Wang, H., Xu, B., Guo, X. (2018). The wisdom of honeybee defenses against environmental stresses. Frontiers in Microbiology, 9, 722. https://doi.org/10.3389/fmicb.2018.00722

Li, G., Zhao, H., Wang, H., Guo, X., Guo, X., Sun, Q., Xu, B. (2016). Characterization of a decapentapletic gene $(A c c D p p)$ from Apis cerana cerana and its possible involvement in development and response 
to oxidative stress. PLoS One, 17(2), e0149117. https://doi.org/10.1371/journal.pone.0149117

Li, J., Heerman, M. C., Evans, J. D., Rose, R., Li, W., Rodríguez-García, C., ... Hamilton, M. (2019). Pollen reverses decreased lifespan, altered nutritional metabolism and suppressed immunity in honey bees (Apis mellifera) treated with antibiotics. Journal of Experimental Biology, 222(7), 1-9. https://doi. org/10.1242/jeb.202077

Liu, T. P. (1984). Ultrastructure of the midgut of the worker honey bee Apis mellifera heavily infected with Nosema apis. Journal of Invertebrate Pathology, 44(3), 282-291. https://doi. org/10.1016/0022-2011(84)90026-0

Liu, T. P. (1996). Varroa mites as carriers of honeybee chalkbrood. American Bee Journal (USA). 136(9).

Lopez-Martinez, G., Elnitsky, M. A., Benoit, J. B., Lee Jr, R. E., Denlinger, D. L. (2008). High resistance to oxidative damage in the Antarctic midge Belgica antarctica, and developmentally linked expression of genes encoding superoxide dismutase, catalase and heat shock proteins. Insect Biochemistry and Molecular Biology, 38(8), 796-804. https://doi. org/10.1016/j.ibmb.2008.05.006

Mallon, E. B., Brockmann, A., Schmid-Hempel, P. (2003). Immune response inhibits associative learning in insects. Proceedings of the Royal Society of London. Series B: Biological Sciences, 2701532), 24712473. https://doi.org/10.1098/rspb.2003.2456

Mao, W., Schuler, M. A., Berenbaum, M. R. (2013). Honey constituents up-regulate detoxification and immunity genes in the western honey bee Apis mellifera. Proceedings of the National Academy of Sciences, 170222), 8842-8846. https://doi. org/10.1073/pnas.1303884110

Martel, A. C., Zeggane, S., Aurières, C., Drajnudel, P., Faucon, J. P., Aubert, M. (2007). Acaricide residues in honey and waxafter treatment of honey bee colonies with Apivar" or Asuntol"50*. Apidologie, 38(6), 534 544. https://doi.org/10.1051/apido:2007038
Martín-Hernández, R., Botías, C., Barrios, L., MartínezSalvador, A., Meana, A., Mayack, C., Higes, M. (2011). Comparison of the energetic stress associated with experimental Nosema ceranae and Nosema apis infection of honeybees (Apis mellifera). Parasitology Research, 109(3), 605-612. https://doi.org/10.1007/ s00436-011-2292-9

May, E., Wilson, J., Isaacs, R. (2015). Minimizing pesticide risk to bees in fruit crops. Extension Bulletin Michigan State University-E3245, 1-16.

Mayack, C., \& Naug, D. (2009). Energetic stress in the honeybee Apis mellifera from Nosema ceranae infection. Journal of Invertebrate Pathology, 10033), 185-188. https://doi.org/10.1016/j.jp.2008.12.001

Mayack, C., \& Naug, D. (2010). Parasitic infection leads to decline in hemolymph sugar levels in honeybee foragers. Journal of Insect Physiology, 56(11), 15721575. https://doi.org/10.1016/j.jinsphys.2010.05.016

McKinstry, M., Chung, C., Truong, H., Johnston, B. A., Snow, J. W. (2017). The heat shock response and humoral immune response are mutually antagonistic in honey bees. Scientific Reports, 78850). https:// doi.org/10.1038/s41598-017-09159-4

McMullan, J. B., \& Brown, M. J. F. (2009). A qualitative model of mortality in honey bee (Apis mellifera) colonies infested with tracheal mites (Acarapis wood). Experimental and Applied Acarology, 47, 225-234. https://doi.org/10.1007/s10493-0089213-3

Medrzycki, P., Sgolastra, F., Bortolotti, L., Bogo, G., Tosi, S., Padovani, E., Porrini, C., Sabatini, A. G. (2010). Influence of brood rearing temperature on honey bee development and susceptibility to poisoning by pesticides. Journal of Apicultural Research, 49(1), 52-59. https://doi.org/10.3896//BRA.1.49.1.07

Meikle, W. G., Adamczyk, J. J., Weiss, M., Gregorc, A., Johnson, D. R., Stewart, S. D., ... Lorenz, G. M. (2016). Sublethal effects of imidacloprid on honey bee colony growth and activity at three sites in the US. PLoS One, 17(12), e0168603. https://doi. org/10.1371/journal.pone.0168603 


\section{J. APPC. SOL. VOL. G5 NO. 12021}

Melicher, D., Wilson, E. S., Bowsher, J. H., Peterson, S. S., Yocum, G. D., Rinehart, J. P. (2019). Longdistance transportation causes temperature stress in the honey bee, Apis mellifera (Hymenoptera: Apidae). Environmental Entomology, 48(3), 691701. https://doi.org/10.1093/ee/nvz027

Moret, Y., \& Schmid-Hempel, P. (2000). Survival for immunity: The price of immune system activation for bumblebeeworkers. Science, 2995494), 1166-1168. https://doi.org/10.1126/science.290.5494.1166

Morimoto, T., Kojima, Y., Toki, T., Komeda, Y., Yoshiyama, M., Kimura, K., Nirasawa, K., Kadowaki, T. (2011). The habitat disruption induces immune-suppression and oxidative stress in honey bees. Ecology and Evolution, 7(2), 201-217. https://doi.org/10.1002/ ece3.21

Motta, E. V., Raymann, K., Moran, N. A. (2018). Glyphosate perturbs the gut microbiota of honey bees. Proceedings of the National Academy of Sciences, 115(41), 10305-10310. https://doi. org/10.1073/pnas.1803880115

Naug, D., \& Camazine, S. (2002). The role of colony organization on pathogen transmission in social insects. Journal of Theoretical Biology, 215(4), 427439. https://doi.org/10.1006/jtbi.2001.2524

Nazzi, F., \& Pennacchio, F. (2014). Disentangling multiple interactions in the hive ecosystem. Trends in Parasitology, 3012), 556-561. https://doi. org/10.1016/j.pt.2014.09.006

Nazzi, F., Brown, S. P., Annoscia, D., Del Piccolo, F." Di Prisco, G., Varricchio, P., ... Pennacchio, F. (2012). Synergistic parasite-pathogen interactions mediated by host immunity can drive the collapse of honeybee colonies. PLoS Pathogens, 8(6), e1002735. https:// doi.org/10.1371/journal.ppat.1002735

Negri, P., Maggi, M. D., Ramirez, L., De Feudis, L." Szwarski, N., Quintana, S., Eguaras, M. J., Lamattina, L. (2015). Abscisic acid enhances the immune response in Apis mellifera and contributes to the colony fitness. Apidologie, 46(4), 542-557. https:// doi.org/10.1007/s13592-014-0345-7
Nelson, C. M., Ihle, K. E., Fondrk, M. K., Page, R. E. Jr., Amdam, G. V. (2007). The gene vitellogenin has multiple coordinating effects on social organization. PLoS Biology, 5(3), e62. https://doi. org/10.1371/journal.pbio.0050062

Ollerton, J., Winfree, R., Tarrant, S. (2011). How many flowering plants are pollinated by animals? Oikos, 1203), 321-326. https://doi. org/10.1111/j.1600-0706.2010.18644.x

Pamminger, T., Botías, C., Goulson, D., Hughes, W. O. H. (2018). A mechanistic framework to explain the immunosuppressive effects of neurotoxic pesticides on bees. Functional Ecology, 32(8), 1921-1930. https://doi.org/10.1111/1365-2435.13119

Perry, C. J., Søvik, E., Myerscough, M. R., Barron, A. B. (2015). Rapid behavioral maturation accelerates failure of stressed honey bee colonies. Proceedings of the National Academy of Sciences, 112(11), 34273432. https://doi.org/10.1073/pnas.1422089112

Perveen, N., \& Ahmad, M. (2017). Toxicity of some insecticides to the haemocytes of giant honeybee, Apis dorsata F. under laboratory conditions. Saudi Journal of Biological Sciences, 24(5), 1016-1022. https://doi.org/10.1016/j.sjbs.2016.12.011

Pettis, J. S., Lichtenberg, E. M., Andree, M., Stitzinger, J., Rose, R., vanEngelsdorp, D. (2013). Crop pollination exposes honey bees to pesticides which alters their susceptibility to the gut pathogen Nosema ceranae. Plos One, 8(7), e70182. https://doi. org/10.1371/journal.pone.0070182

Pettis, J. S., vanEngelsdorp, D., Johnson, J., Dively, G. (2012). Pesticide exposure in honey bees results in increased levels of the gut pathogen Nosema. Naturwissenschaften, 99(2), 153-158. https://doi.org/10.1007/s00114-011-0881-1

Ponnappan, S., \& Ponnappan, U. (2011). Aging and immune function: molecular mechanisms to interventions. Antioxidants \& Redox Signaling, 14(8), 1551-1585.https://doi.org/10.1089/ ars.2010.3228 


\section{KHUR ET HL.___ Factors affecting the immunity in honey bees}

Potts, S. G., Biesmeijer, J. C., Kremen, C., Neumann, P." Schweiger, O., Kunin, W. E. (2010). Global pollinator declines: trends, impacts and drivers. Trends in Ecology \& Evolution, 25(6), 345-353. https://doi. org/10.1016/j.tree.2010.01.007

Rabasa, C., \& Dickson, S. L. (2016). Impact of stress on metabolism and energy balance. Current Opinion in Behavioral Sciences, 9, 71-77. https://doi. org/10.1016/j.cobeha.2016.01.011

Ramsey, S. D., Ochoa, R., Bauchan, G., Gulbronson, C., Mowery, J. D., Cohen, A., ... vanEngelsdorp, D. (2019). Varroa destructor feeds primarily on honey bee fat body tissue and not hemolymph. Proceedings of the National Academy of Sciences, 116(5), 17921801. https://doi.org/10.1073/pnas.1818371116

Ratnieks, F. L. W., \& Carreck, N. L. (2010). Clarity on honey bee collapse? Science, 3275962), 152-153. https://doi.org/10.1126/science.1185563

Richards, E. H., Jones, B., Bowman, A. (2011). Salivary secretions from the honeybee mite, Varroa destructor. effects on insect haemocytes and preliminary biochemical characterization. Parasitology, 138(5), 602-608. https://doi. org/10.1017/S0031182011000072

Richardson, R. T., Ballinger, M. N., Qian, F., Christman, J. W., Johnson, R. M. (2018). Morphological and functional characterization of honey bee, Apis mellifera, haemocyte cell communities. Apidologie, 49(3), 397-410. https://doi.org/10.1007/s13592018-0566-2

Riessberger, U., \& Crailsheim, K. (1997). Short-term effect of different weather conditions upon the behaviour of forager and nurse honey bees (Apis mellifera carnica Pollmann). Apidologie, 28(6), 411426. https://doi.org/10.1051/apido:19970608

Riessberger-Gallé, U., Hernández López, J., Schuehly, W., Crockett, S., Krainer,S., Crailsheim, K. (2015).Immune responses of honeybees and their fitness costs as compared to bumblebees. Apidologie, 46(2), 238249. https://doi.org/10.1007/s13592-014-0318-х
Ryabov, E. V., Wood, G. R., Fannon, J. M., Moore, J. D., Bull, J. C., Chandler, D., ... Evans, D. J. (2014). A virulent strain of deformed wing virus (DWV) of honeybees (Apis mellifera) prevails after Varroa destructor-mediated, or in vitro, transmission. PLoS Pathogens, 196), el004230. https://doi.org/10.1371/journal.

ppat.1004230

Salem, M. H., Gad, A. A., Ramadan, H. M. (2006). Effect of Varroa destructor on different haemocyte count, total haemolymph protein on larvae, pupae and adults of Apis mellifera drones. Journal of the Egyptian Society of Toxicology, 35, 93-96.

Sammataro, D., Gerson, U., Needham, G. (2000). Parasitic mites of honey bees: life history, implications, and impact. Annual Review of Entomology, 45, 519548. https://doi.org/10.1146/annurev.ento.45.1.519

Sánchez-Bayo, F., Goulson, D., Pennacchio, F., Nazzi, F., Goka, K., Desneux, N. (2016). Are bee diseases linked to pesticides?- A brief review. Environment International, 89-90, 7-11. https://doi.org/10.1016/j. envint.2016.01.009

Sanjerehei, M. M. (2014). The economic value of bees as pollinators of crops in Iran. Annual Research \& Review in Biology, 4(19), 2957-2964. https://doi. org/10.9734/ARRB/2014/10200

Schmid, M. R., Brockmann, A., Pirk, C. W., Stanley, D. W., Tautz, J. (2008). Adult honeybees (Apis mellifera L.) abandon hemocytic, but not phenoloxidase-based immunity. Journal of Insect Physiology, 54(2), 439444. https://doi.org/10.1016/j.jinsphys.2007.11.002

Schmid-Hempel, P. (2005). Evolutionary ecology of insect immune defenses. Annual Review of Entomology, 50, 529-551. https://doi.org/10.1146/ annurev.ento.50.071803.130420

Seeley, T. D. (2014). Honeybee ecology: a study of adaptation in social life (Vol. 36). Princeton University Press.

Sharma, R., \& Martins, N. (2020). Telomeres, DNA damage and ageing: potential leads from Ayurvedic Rasayana (anti-ageing) drugs. Journal of Clinical 


\section{」. APIC. SUL. VOL. 65 ND. 12021}

Medicine, 98), 2544. https://doi.org/10.3390/ jcm9082544

Sharma, R., \& Prajapati, P. K. (2014). Diet and lifestyle guidelines for diabetes: Evidence based Ayurvedic perspectives. Romanian Journal of Diabetes Nutrition and Metabolic Diseases, 27(4), 335-46.

Sharma, R., Martins, N., Chaudhary, A., Garg, N., Sharma, V., Kuca, K.,... Prajapati, P. K. (2020). Adjunct use of honey in diabetes mellitus: A consensus or conundrum? Trends in Food Science \& Technology, 106, 254-274. https://doi.org/10.1016/j. tifs.2020.10.020

Sharma, R., Martins, N., Kuca, K., Chaudhary, A., Kabra, A., Rao, M.M., Prajapati, P.K. (2019). Chyawanprash: A Traditional Indian Bioactive Health Supplement. Biomolecules, 9(5), 161. https://doi.org/10.3390/ biom9050161

Shen, M., Yang, X., Cox-Foster, D., Cui, L. (2005). The role of varroa mites in infections of Kashmir bee virus (KBV) and deformed wing virus (DWV) in honey bees. Virology, 342(1), 141-149. https://doi. org/10.1016/j.virol.2005.07.012

Sies, H. (2000). What is oxidative stress? In: Keaney, J. F. (Eds), Oxidative stress and vascular disease (pp. 1-8). Springer, Boston, MA.

Sihag, R. C. (2014). Phenology of migration and decline in colony numbers and crop hosts of giant honeybee (Apis dorsata F.) in semiarid environment of Northwest India. Journal of Insects, 2014. Article ID 639467. http://dx.doi. org/10.1155/2014/639467

Simone-Finstrom, M. (2017). Social immunity and the superorganism: Behavioral defenses protecting honey bee colonies from pathogens and parasites. Bee World, 94(1), 21-29. https://doi.org/1 0.1080/0005772X.2017.1307800

Simone-Finstrom, M. D., \& Spivak, M. (2012). Increased resin collection after parasite challenge: a case of self-medication in honey bees? PLoS One, 73), e34601. https://doi.org/10.1371/journal. pone.0034601

Simone-Finstrom, M., Li-Byarlay, H., Huang, M. H., Strand, M. K., Rueppell, O., Tarpy, D. R. (2016). Migratory management and environmental conditions affect lifespan and oxidative stress in honey bees. Scientific Reports, 6. https://doi. org/10.1038/srep32023

Siva-Jothy, M. T., \& Thompson, J. J. W. (2002). Shortterm nutrient deprivation affects immune function. Physiological Entomology, 273), 206-212. https://doi.org/10.1046/j.1365-3032.2002.00286.x

Southwick, E. E., \& Heldmaier, G. (1987). Temperature control in honey bee colonies. Bioscience, 376), 395-399.

Spivak, M., \& Reuter, G. S. (2001). Resistance to American foulbrood disease by honey bee colonies Apis mellifera bred for hygienic behavior. Apidologie, 32(6), 555-565. https://doi. org/10.1051/apido:2001103

Stanimirović, Z., Glavinić, U., Ristanić, M., Aleksić, N., Jovanović, N., Vejnović, B., Stevanović, J. (2019). Looking for the causes of and solutions to the issue of honey bee colony losses. Acta Veterinaria, 69(1), 1-31. https://doi.org/10.2478/acve-2019-0001

Starks, P. T., Blackie, C. A., Seeley, T. D. (2000). Fever in honeybee colonies. Naturwissenschaften, 875), 229-231.

Steinmann, N., Corona, M., Neumann, P., Dainat, B. (2015). Overwintering is associated with reduced expression of immune genes and higher susceptibility to virus infection in honey bees. PLoS One, 196), e0129956. https://doi.org/10.1371/ journal.pone.0129956

Strand, M. R. (2008). The insect cellular immune response. Insect Science, 15(1), 1-14. https://doi. org/10.1111/j.1744-7917.2008.00183.x

Strauss, U., Pirk, C. W., Crewe, R. M., Human, H., Dietemann, V. (2015). Impact of Varroa destructor on honeybee (Apis mellifera scutellata) colony 


\section{_ KAUH ET HLL__ Factors affecting the immunity in honey bees}

development in South Africa. Experimental and Applied Acarology, 65(1), 89-106. https://doi. org/10.1007/s10493-014-9842-7

Szymaś, B., \& Jędruszuk, A. (2003). The influence of different diets on haemocytes of adult worker honey bees, Apis mellifera. Apidologie, 34(2), 97102. https://doi.org/10.1051/apido:2003012

Trenczek, T., \& Faye, I. (1988). Synthesis of immune proteins in primary cultures of fat body from Hyalophora cecropia. Insect Biochemistry, 18(3), 299-312. https://doi.org/10.1016/00201790(88)90095-9

van der Zee, R., Pisa, L., Andonov, S., Brodschneider, R., Charriere, J. D., Chlebo, R., ... Wilkins, S. (2012). Managed honey bee colony losses in Canada, China, Europe, Israel and Turkey, for the winters of 2008-9 and2009-10. Journal of ApiculturalResearch, 57(1), 100-114. https://doi.org/10.3896//BRA.1.51.1.12

van Dooremalen, C., Gerritsen, L., Cornelissen, B. van der Steen, J. J. M., van Langevelde, F. Blacquiere, T. (2012). Winter survival of individual honey bees and honey bee colonies depends on level of Varroa destructor infestation. Plos One, 74), e36285. https://doi.org/10.1371/journal.pone.0036285

van Dooremalen, C., Stam, E., Gerritsen, L., Cornelissen, B., van der Steen, J., van Langevelde, F., Blacquière, T. (2013). Interactive effect of reduced pollen availability and Varroa destructor infestation limits growth and protein content of young honey bees. Journal of Insect Physiology, 59(4), 487-493. https:/l doi.org/10.1016/j.jinsphys.2013.02.006

Vandame, R., \& Belzunces, L. P. (1998). Joint actions of deltamethrin and azole fungicides on honey bee thermoregulation. Neuroscience Letters, 257(1), 57-60. https://doi.org/10.1016/ S0304-3940(98)00494-7

vanEngelsdorp, D., \& Meixner, M. D. (2010). A historical review of managed honey bee populations in Europe and the United States and the factors that may affect them. Journal of Invertebrate Pathology, 103, s80-S95, https://doi.org/10.1016/j.

\section{jip.2009.06.011}

Weidner, E., Findley, A. M., Dolgikh, V., Sokolova, J. (1999). Microsporidian biochemistry and physiology. In: Wittner, M., \& Weiss, L. (Ed), The microsporidia and microsporidiosis (pp. 172-195). American Society of Microbiology. http://dx.doi. org/10.1128/9781555818227.ch5

White Jr, J. W., Subers, M. H., Schepartz, A. I. (1963). The identification of inhibine, the antibacterial factor in honey, as hydrogen peroxide and its origin in a honey glucose-oxidase system. Biochimica et Biophysica Acta (BBA)-Specialized Section on Enzymological Subjects, 73(1), 57-70.

Wilson-Rich, N., Dres, S. T., Starks, P. T. (2008). The ontogeny of immunity: development of innate immune strength in the honey bee (Apis mellifera). Journal of Insect Physiology, 54(1011), 1392-1399. https://doi.org/10.1016/j. jinsphys.2008.07.016

Wilson-Rich, N., Spivak, M., Fefferman, N. H., Starks, P. T. (2009). Genetic, individual, and group facilitation of disease resistance in insect societies. Annual Review of Entomology, 54, 405-423. https://doi. org/10.1146/annurev.ento.53.103106.093301

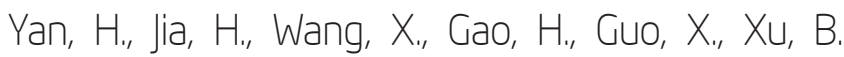
(2013). Identification and characterization of an Apis cerana cerana Delta class glutathione S-transferase gene (AccGSTD) in response to thermal stress. Naturwissenschaften, 10022), 153163. https://doi.org/10.1007/s00114-012-1006-1

Yoshida, Y. (1988). Cytochrome P450 of fungi: primary target for azole antifungal agents. In: McGinnis, M. R. (Eds), Current Topics in Medical Mycology (pp. 388-418). Springer, New York, NY. https://doi.org/10.1007/978-1-4612-3730-3_11

Zakaria, M. E. (2007). The cellular immunity responses in the haemolymph of honey bee workers infected by American foulbrood disease (AFB). Journal of Applied Sciences Research, 3(1), 56-63.

Zhu, M., Zhang, W., Liu, F., Chen, $X_{\text {., }} L i, H_{\text {., }} X u$, B. 
(2016). Characterization of an Apis cerana cerana cytochrome P450 gene (AccCYP336A) and its roles in oxidative stresses responses. Gene, 584(2), 120128. https://doi.org/10.1016/j.gene.2016.02.016 